\title{
The medicinal value and the numerous sources of vitamin c - a review
}

\begin{abstract}
Vitamin $\mathrm{C}$ is one of the nine water soluble vitamins which approximate a carbohydrate in structure. The transport takes place via glucose transporters and the absorption eventualizes in the gastrointestinal tract. It has a myriad of biological roles in the body and due to which it has abundant medicinal roles. These medicinal roles of Vitamin $\mathrm{C}$ can be subdivided as prevented and curative. The systems which are benefitted by Vitamin $\mathrm{C}$ include cardiovascular system, neurovascular system, musculoskeletal system, gastrointestinal system to name some. The review embodies various medicinal uses and sources along with the effect of food processing on the concentration of Vitamin C.
\end{abstract}

Keywords: ascorbic acid, vitamin, cancer, cardiovascular disease, diabetes, fruits, vegetables
Volume 2 Issue 4 - 2015

\author{
Hansa Jain \\ University of Edinburgh, UK
}

Correspondence: Hansa Jain, MPH- Public Health, University of Edinburgh, Edinburgh, UK, Email drhansaliljain@gmail.com

Received: May 10,2015 | Published: September 10, 2015
Abbreviations: VC, vitamin c; L-AA, 1-ascorbic acid; DHA, 1-dehydroascorbic acid; GLO, 1-gulonolactone oxidase gene; LDL, low density lipoprotein; HDL, high density Lipoprotein; DV, dentate gyrus; FG, fasting; PBG, post meal blood glucose; GHb, glycosylated hemoglobin; $\mathrm{AD}$, alzheimer's disease

\section{Introduction}

Polish biochemist Kazimierz Funk while working on experimental beriberi, gave the name "Vitaimine" from the words vital and amine meaning amine of life but then later the word "Vitamin" was acceptable in 1920 under the standard scheme of nomenclature adopted by the Chemical Society. McCollum classified vitamins as either watersoluble or fat-soluble, the total numbers of vitamins in humans are 13, enlisting 4 fat soluble vitamins i.e. A, D, E, K and 9 water soluble vitamins i.e. B complex and C., ${ }^{1,2}$ Vitamin $\mathrm{C}$ (VC), a water soluble vitamin has an oblong crystalline structure which is white in colour. Its general formula is $\mathrm{C} 6 \mathrm{H} 6 \mathrm{O} 5$ and its structural formula resembles a carbohydrate. ${ }^{3,4} \mathrm{~L}$-ascorbic acid (L-AA) is the main biologically active form of $\mathrm{VC}$, reversible oxidation of L-AA results in formation of L-dehydroascorbic acid (DHA) which also has biological activity. ${ }^{5}$

Human beings are unable to synthesize VC on their own due to mutation of the 1-gulonolactone oxidase gene (GLO). The last step in the synthesis of VC is catalyzed by GLO and inability of humans to synthesize VC is due to GLO deficiency in them. Humans and rats (the species that are able to synthesize) have homologous GLO genes but in man the gene has been mutated several times making the gene inactive. ${ }^{6,7} \mathrm{On}$ intake of $\mathrm{VC}$, its level in a healthy individual varies between $0.7-1.5 \mathrm{mg} / 100 \mathrm{ml}$ of plasma. Concentration of $\mathrm{VC}$ in blood cells is much higher than in plasma, i.e. 3-4times higher in red blood cells and 20-30 times higher in white blood cells. Adrenals contain the highest concentration of $\mathrm{VC}$ amongst organs and the concentration of Vitamin $\mathrm{C}$ decreases with age, alcoholism and with intake of contraceptive pills. ${ }^{4}$

\section{Metabolism}

The two major forms of $\mathrm{VC}$ available in diet are L-AA, which is, as mentioned physiologically reducing agent and DHA, which is the oxidized form. DHA is absorbed by facilitated transport, which takes place with the help of glucose transporters particularly GLUT1, GLUT3 and GLUT9. Transport of L-AA is mediated by sodium dependent SVCT1 and $\mathrm{SVCT}_{2}{ }^{8}$ and the absorption takes place in the gastrointestinal tract. A large number of factors have been observed to affect the absorption, these enlist route of ingestion, quantity of the vitamin ingested, and prior nutritional status of the individual. The metabolites of vitamin $\mathrm{C}$ in humans are oxalate, dehydro-ascorbic acid, 2,3-diketogulonic acid, ascorbic acid 2-sulphate and saccharoascorbic acid. Maximum concentration of these compounds have been isolated and identified in urine, whereas the average faecal excretion of $\mathrm{VC}$ or its metabolites was observed to be about $3 \%$ when administered orally in physiological amounts. ${ }^{9}$

\section{Medicinal role}

Intake of $\mathrm{VC}$ has been associated with the prevention and treatment of an ample number of diseases due to its various biological properties. Its medicinal uses can be assorted as disease prevention and disease treatment.

\section{Disease prevention}

Cancer: VC intake has been associated with the prevention of a number of cancers, many clinical trials have reported in which consumption of VC helped in reducing the occurrence of tumours in oral cavity, larynx, oesophagus, lungs, pancreas, stomach, colorectal, bladder and brain. McLaughlin et al., ${ }^{10}$ studied VC consumption and incidence of oral cancer and the results presented that the reduced intake of vitamin $\mathrm{C}$ was associated with increased risk for cancer. Graham et al., ${ }^{11}$ carried out a study to observe effect of VC on cancer of larynx by carrying out a survey and reported that lower ingestion of the vitamin was associated with higher incidence of the cancer of larynx. Cancer of the oesophagus was also studied by a number of investigators ${ }^{12-14}$ and the studies have presented that $\mathrm{VC}$ or fruit intake has a strong inverse relationship with incidence of cancer of oesophagus independent of all factors.

Fontham et al., ${ }^{15}$ examined approximately 2500 subjects including lung cancer patients and controls. On adjusting with other factors it was observed that higher intake of $\mathrm{VC}$ was related to decrease in risk 
for the disease. Kromhout ${ }^{16}$ analysed the results of a prospective study and confirmed that incidence of lung cancer and intake of vitamin C has a strong inverse association. In a study Falk et al., ${ }^{17}$ investigated cases of pancreatic cancer and matched hospital controls. They carried out a survey with regards to the diet of the individuals and it was observed that those who consumed less than $70 \mathrm{mg}$ vitamin $\mathrm{C} /$ day had a relative risk of 2.6 for males, or 1.8 for females compared with those who consumed $59 \mathrm{mg} / \mathrm{d}$. Another study by Mills et al. stated that frequent consumption was significantly protective against pancreatic cancer. ${ }^{18}$ Along with these literature also suggests preventive role of $\mathrm{VC}$ against carcinomas of stomach, cervix, colon and rectum. ${ }^{19-21}$

N-Nitroso compounds including dialkyl-N-nitrosa-mines, $\mathrm{N}$-alkyl-N-nitrosamides, and related compounds are an important group of environmental carcinogens. VC decreases formation of nitrosamine formation whereas lipid-soluble derivatives of $\mathrm{VC}$ are also very efficient in reducing the nitrosamine content of foods..$^{22} \mathrm{VC}$ induces apoptosis in the cells through the disruption of mitochondrial membrane potential and by suppressing the translocation of transferring receptor from cytosol to membrane. It also attenuates the proliferation of cancer cells via prevention of growth of these cells. It arrests the growth at G1 stage which has approximity with the modulation of the activity of p53-p21Waf1/Cip1 and CDK2. ${ }^{23}$

Cardiac diseases: Oxidative modification of low density lipoprotein (LDL) increases atherogenicity as it is taken up more quickly by macrophages, monocytes and smooth muscle cells beneath the arterial endothelium and results in increased accumulation of cholesterol ester leading to formation of foam cells and the initiation of the lesion of atherosclerosis. Other methods by which it causes atherogenesis is by retaining monocyte-macrophages in the arterial wall and by being cytotoxic towards endothelial cells. VC has protective role against oxidation of LDL, it even preserves the endogenous antioxidants in LDL. ${ }^{24,25}$ It has been observed that $\mathrm{VC}$ along with DHA prevent the initiation of lipid peroxidation in LDL and also preserved the LDLassociated antioxidants like $\alpha$-tocopherol, $\beta$-carotene, and lycopene, infact VC works synergistically with vitamin E, ubiquinol-10, $\beta$-carotene in LDL to suppress the peroxidation. ${ }^{26,27}$

$\mathrm{VC}$ increases level of high density lipoprotein (HDL) and this association was stronger in older people and in males than in younger people and in females. ${ }^{28}$ In patients suffering from elevated total cholesterol levels if $\mathrm{VC}$ is administered in high dose, there is reduction in total cholesterol levels. ${ }^{29}$ Vasodilation is compromised in patients with atherosclerosis and this may lead to myocardial infarction and stroke. Literature suggests that administration of $\mathrm{VC}$ results in improved vasodilation in patients of coronary heart disease, angina pectoris, congestive heart failure, diabetes, high cholesterol, and high blood pressure. ${ }^{30-34}$

Lead Toxicity: Lead increases the level of lipid peroxidation and brain thiobarbituric acid-reactive substances, decreases the capacity of antioxidant defence system and even decreases blood haemoglobin, glutathione peroxidise, superoxide dismutase levels and liver glutathione levels. Various clinical trials have concluded that on administration of $\mathrm{VC}$ alone or in combination with other agents there is decrease in lead concentration and there is lesser tissue damage which is otherwise caused by increased lead levels in the body. In a study vitamin $\mathrm{C}$ and vitamin $\mathrm{B}$ were administered to counteract the effect of high lead concentration and it was concluded that both the vitamins reduced the damage to liver cells from oxidative damage caused by lead, but their effect was dependent on their concentration. ${ }^{35}$ Ebuehi et al., ${ }^{36}$ administered vitamin $\mathrm{C}$ and vitamin
E to evaluate their effect in attenuating hepatotoxicity and oxidative stress caused by lead and the study presented that administration of the vitamins reduced the toxic effects induced by lead. As mentioned lead intake decreases blood haemoglobin, in a study VC was given along with iron to examine their effect on anaemia caused by lead. Their intake prevented the growth depression and anaemia caused and reduced tissue lead contents, specifically in bone in which most of the accumulated lead was observed to be present. ${ }^{37}$ Goyer and Cherian ${ }^{38}$ claimed that chelating effect of $\mathrm{VC}$ was equivalent to that of EDTA when examined in relation to lead toxicity.

Lead causes alterations in hematopoietic system and drug metabolizing enzymes, keeping this in view Vij et al., ${ }^{39}$ examined the effect of $\mathrm{VC}$ in restoring normal physiology in male rats. They concluded that administering VC restored blood delta aminolevulinic acid dehydratase, uroporphyrinogen I synthetase and a few drug metabolizing enzymes and a significant reduction in lead concentration of blood and liver. In another study reduction in neurotoxic effects including neuronal damage and apoptotic cell death was investigated in rats. The rats were given $100 \mathrm{mg} / \mathrm{kg} / \mathrm{day}$ of $\mathrm{VC}$ and histopathological evaluation presented that VC reduced apoptosis in the developing hippocampus and also spares hippocampal CA1, CA3 and dentate gyrus (DG) neuron and blood levels of lead. ${ }^{40}$

Bone: $\mathrm{VC}$ is a cofactor in the hydroxylation of proline and lysine. The intracellular level of VC in osteoblasts is regulated by sodium dependent transporter proteins present in the plasma membrane. $\mathrm{VC}$ reduces the iron prosthetic group of the hydroxylases and thus appears to play a pivotal role in maintenance of bone health. Its lower intake has been related to reduced bone mass and increase in rate of bone loss, increase in frequency of fractures and higher occurrence of osteoporosis. It is suggested that $\mathrm{VC}$ enhances bone health and its low level plays a significant role in development of osteoporosis. VC stimulates assembling of fibril and also the proliferation of various cell types. It plays major role in both proliferation of osteoblasts and even in their differentiation to generate bone matrix proteins. In a study effect of vitamin $\mathrm{C}$ concentration on osteoblasts was examined and the results presented that the proliferation of these bone forming cells increased with increase in VC and the highest proliferation was observed at level of $200 \mu \mathrm{g} / \mathrm{ml}$ but at the concentration of $300 \mu \mathrm{g} / \mathrm{ml}$ and above $\mathrm{VC}$ appeared to be toxic. It is also observed that osteoblasts increase the expression of osteonectin and osteocalcin on adding vitamin C. ${ }^{41,42}$

A population based cohort study by Sahni et al., ${ }^{43}$ was conducted to evaluate the role of $\mathrm{VC}$ on bone mineral density and a positive correlation was observed between the two. Rodriguez et al., ${ }^{44}$ described a case of regional transient osteoporosis of the foot. When the patient was evaluated radiologically severe osteopenia in the feet and bone marrow oedema was observed. The authors concluded that these finding were related to severe vitamin $\mathrm{C}$ deficiency. Lynch et al. observed an unusual form of osteoporosis in Johannesburg subjects and noticed a significant correlation with vitamin $\mathrm{C}$ deficiency. ${ }^{45}$

Ocular Tissue: $\mathrm{VC}$ is present in the eye structure of many species and its concentration is higher than in other tissues. The level of VC in eye is highest in aqueous humor and lowest in retina and it has been generally considered that aqueous humor serves as the source of $\mathrm{VC}$ in the ocular tissues. ${ }^{46,47}$ The considered primary role of $\mathrm{VC}$ in the ocular tissues is to provide protection against oxidative damage and precisely the damage induced by light..$^{48}$ Reiss et al. ${ }^{46}$ stated that the high concentration of ascorbate in the eye might be an adaptation of the ocular tissue to protect itself from solar radiation. VC prevents the 
riboflavin-mediated, light-induced damage to the cation pump in the lens ${ }^{49,50}$ and even lowers the photoperoxidation of the membranes. ${ }^{51}$

Cataracts are a leading cause of visual impairment throughout the world. Consumption of VC has been observed to show an inverse relationship with occurrence of cataract. Few studies have concluded that increased dietary vitamin $\mathrm{C}$ intake $\mathrm{k}^{52,53}$ and increased blood levels of vitamin $\mathrm{C}^{54}$ to be associated with decreased risk of cataracts. VC has protective effect on all three types of cataracts including cortical, nuclear, and posterior subcapsular but most on posterior sub-capsular type. ${ }^{55,56}$

Gout: VC supplementation is observed to provide protective effects against gout as it reduces hyperuricemia which is a precursor of gout. The protective effect of vitamin $\mathrm{C}$ against hyperuricemia is due to its competition with uric acid for renal reabsorption via an anion-exchange transport system in the proximal tubules. ${ }^{57}$ Enomoto et al. ${ }^{58}$ in 2002 stated that the other mechanism behind it might be through inhibition of urate transporter 1 which is the main target for uricosurics or inhibition of Na-dependent anion co-transporter or both in the proximal tubule. Huang et al. ${ }^{59}$ conducted a clinical trial and concluded that on administration of $500 \mathrm{mg} /$ day there was significant increase in glomerular filtration rate hence giving another mechanism behind uricosuric effect of VC. A study in USA stated that after supplementation with VC there was a decrease of $45 \%$ in level of uric acid with intake of $1500 \mathrm{mg}$ or more and about $34 \%$ lower risk for vitamin C intake between 1000 and $1499 \mathrm{mg} /$ day compared to no intake of vitamin $\mathrm{C}$ and the results obtained were independent of diet body mass index, age, hypertension, diuretic use, alcohol, and chronic renal failure. ${ }^{60}$

Hypervitaminosis A: Rodahl observed that detrimental effects of hypervitaminosis A were increased in animals suffering from deficiency of vitamin $\mathrm{C}$ than in non-scorbutic animals. ${ }^{61}$ Wendt and Schroeder stated that administration of VC had favourable action on toxic effects of hypervitaminosis A and delayed deposition of the vitamin in the liver. ${ }^{62}$

\section{Treatment}

Diabetes: It has been reported that leukocyte VC levels of diabetic patients is low as compared to non-diabetic on giving both kind of subjects same amount of the vitamin and it reduces the level of advanced glycation end products which are formed by irreversible glycation of proteins in oxidative conditions. ${ }^{63}$ In a study by Osganian et al. ${ }^{64}$ intake of $\mathrm{VC}$ in the dose of $400 \mathrm{mg}$ /day or more was observed to reduce the fatal and nonfatal coronary heart disease in diabetics. Levy et al. ${ }^{65}$ studied intake of vitamins and their impact on the progression of coronary artery atherosclerosis and the results presented that vitamin supplementation was related with improvement in coronary artherosclerosis in diabetic females having two copies of haptoglobin 1 gene whereas the condition worsened in diabetic females having two copies of haptoglobin 2 gene thus claiming that genetic factors of the individual also play a primary role. In an experiment effect of $\mathrm{VC}$ on diabetes induced endothelial dysfunction and generation of reactive oxygen species was examined. The results showed that reduced VC was associated with increased dihydrorhodamine 123 , which is an indication of increase in microvascular oxidative stress. Endothelial dysfunction was observed to be reduced or completely eliminated on administration of VC. ${ }^{66}$

In a study effect of vitamin $\mathrm{C}$ along with metformin on fasting (FG) and post meal blood glucose (PBG) and glycosylated hemoglobin
$(\mathrm{GHb})$ in patients with type 2 diabetes was evaluated. It was observed that there was an identifiable decrease in FG and PBG with increase in $\mathrm{VC}$ levels. The proposed dose of $\mathrm{VC}$ was $1,000 \mathrm{mg} / \mathrm{day}$ which was found to be simple, safe, and an effective means of preventing and decreasing chronic complications of diabetes. The proposed mechanism was its antioxidant capacity by providing protection from the oxygen species and even to $\beta$ cells from getting damaged, other reason for beneficial effect of $\mathrm{VC}$ in diabetes is positive action of $\mathrm{VC}$ on vitamin E. ${ }^{67}$ Literature suggests that diabetics have increased occurrence of gastric ulceration, in a study effect of $\mathrm{VC}$ on this manifestation of diabetes was examined. The study concluded that $\mathrm{VC}$ shows protective effects on mucosa of stomach from formation of peptic ulcers and even increase secretion of gastric acid without disturbing the cytoarchitecture of the gastric mucosa. ${ }^{68}$

Cognitive impairment: Oxidative damage to neuronal cell membranes and mitochondrial DNA has been proposed to cause Alzheimer's disease (AD) whereas oxidation of LDL enhances the risk of vascular dementia. ${ }^{69}$ Due to this reason VC therapy has also been proposed in cognitive impairment. $\mathrm{VC}$ acts as a scavenger of free radicals in the brain and lower levels of this vitamin has been related to occurrence of $\mathrm{AD}$. Charlton et al., ${ }^{70}$ evaluated levels of $\mathrm{VC}$ in patients with dementia and $\mathrm{AD}$. It was observed that patients suffering from $\mathrm{AD}$ or senile dementia had lower plasma $\mathrm{VC}$ levels than control subjects of same age group. It has also been stated that even in a healthy elderly, a higher level of plasma vitamin $\mathrm{C}$ was associated with better cognitive functioning. The authors suggested that adequate dose of VC to play its cognitive function would be $200 \mathrm{mg} /$ day. Perrig et al. ${ }^{71}$ followed 446 Swiss subjects for 22years and concluded that high serum level of AA was associated with superior performance on tests of memory. Several cross sectional and case-control studies of cognitive impairment have observed that cognitive impairment is associated with lower levels of serum vitamin C..$^{72,73}$

Pulmonary function: $\mathrm{VC}$ has been shown to improve pulmonary function, Bucca et al. administered VC to patients suffering from bronchial reactive conditions caused by infections, allergy or exposure to air pollution or cigarette smoke. It was observed that $\mathrm{VC}$ prevented the increase in bronchial activity induced by foreign particle, due to allergic reaction or infection. Pathophysiologically, inflammation in the respiratory tissue attracts a number of neutrophil to the lung and these activated neutrophils generate oxygen free radicals. These species interact with $\alpha-1$-protease thus leading to inhibition of proteolysis. $\mathrm{VC}$ protects $\alpha$-1-protease from free radicals as well as from cigarette smoke. ${ }^{74}$ Low concentration of the vitamin causes reduction in forced expiratory volume. It attenuates bronchoconstriction caused due to inhalation of nitrogen dioxide and ozone and even reduces bronchial reactivity to histamine and methacholine. ${ }^{75} \mathrm{VC}$ has antibronchospastic action in subjects with exercise induced bronchospasm. ${ }^{76}$

$\mathrm{VC}$ levels in asthmatics have been observed to be reduced and it has also been stated that $\mathrm{VC}$ has a protective effect on asthma. ${ }^{77}$ On giving $\mathrm{VC}$ to asthmatics the frequency and severity of attacks reduces. ${ }^{78}$ Its administration with standard anti-asthmatics improves leukocyte motility, reduces antistreptolysin $\mathrm{O}$ levels and reduces immunoglobulin-E levels and titres of antibodies to the respiratory viruses. ${ }^{79}$ In a study it was observed that vitamin $\mathrm{C}$ was significantly associated with a lower risk of prevalent asthma, with highest association with the subgroup of youngsters exposed to cigarette smoke. ${ }^{80}$ Brittle asthma is a rare form of severe asthma in which patient suffers from repeated life threatening attacks. There is 
increased risk of mortality and morbidity in patients suffering from brittle asthma. VC has also been observed to play a pivotal role in pathophysiology of brittle asthma as well. It was observed that the nutrient intake of vitamin $\mathrm{C}$ was lesser in patients with brittle asthma than in other cases. ${ }^{81}$

Cancer: Few studies carried out in 1970s and 1980s have reported that on administration of large dosage of $\mathrm{VC}$ result in increase in the survival time and improvement of the quality of life of patients in the last stage of cancer. ${ }^{82}$ Gottlieb $^{83}$ stated that VC fights back the oxidative damage induced during chemotherapy and radiation therapy thus helps in inhibition of the growth of cancerous cells. Prasad et al found that high doses of VC not only can protect normal cells during cancer treatment but also can help fight tumours. At the level of 5 $\mathrm{mM}$ it causes a decrease of $50 \%$ in survival of cancer cells and the processes like apoptosis, pyknosis and necrosis are dependent on intracellular ascorbate. The destruction of cancer cells depend on concentration of hydrogen peroxide formation which is generated by ascorbate in the extracellular medium. ${ }^{84}$

In a study An et al., ${ }^{85}$ studied effect of VC during treatment of colon cancer. It was observed that co-administration of $\mathrm{VC}$ with a cancer drug cisplatin increases sensitivity of the cancer cells towards the drug and even modifies tumour suppressor gene p58, thus enhancing the treatment results and further prognosis. It also increases the tumoricidal action of dacarbazine, tamoxifen, doxorubicin and paclitaxel. ${ }^{86,87}$ When $\mathrm{VC}$ is administered along with vitamin $\mathrm{K}$, the combination enhances the therapeutic effect of six different chemotherapy agents ${ }^{88}$ Inflammation has a pivotal role in development of tumours as it affects tumour proliferation, angiogenesis, metastasis and causes resistance to therapy. The features of inflammation related to cancer development are leukocyte infiltration, cytokine build-up, tissue remodelling and angiogenesis. The infiltrated leukocyte includes cytokines such as IL1, IL6, TNF $\alpha$, TGF $\beta$, FGF, EGF and HGF21, as well as chemokines such as CCL2 and CXCL8. Administration of VC reduces inflammation, in a study it was indicated that on intake of $\mathrm{VC}$ there was reduction in production of IL-2, IL-6 and TNF $\alpha$. When VC is given through IVC therapy it attenuates cancer cell production and proliferation. ${ }^{23}$

Common Cold: Usage of AA in treatment of common cold was first documented in $1930 \mathrm{~s} .{ }^{89}$ Since then a large number of clinical trials have been conducted to test the hypothesis. In a Cochrane systematic review it was stated that a clinical trial observed administration of $8 \mathrm{~g}$ of $\mathrm{VC}$, the symptoms had more "short colds" of lesser severity than a day with administration of $4 \mathrm{~g}$. The review also mentioned that with intake of $1 \mathrm{~g}$ daily of $\mathrm{VC}$ the symptoms reduced in both adults as well as children..$^{90}$ Constantini et al.,91evaluated role of $\mathrm{VC}$ in treatment and prevention of upper respiratory tract infections in swimmers. They concluded that $\mathrm{VC}$ reduced the severity and duration of the infection in males but not in females. Maggini et al., ${ }^{92}$ co-administered vitamin $\mathrm{C}$ along with zinc and claimed that their co-administration reduced the duration of rhinorrhoea and the severity of symptoms.

\section{Deficiency of vitamin C}

\section{Scurvy}

Scurvy, disease caused due to deficiency of vitamin C. the disease has its initials in the late bronze age, its description was written in Ebers Papyrus (1500 B.C.) and was even mentioned by Socrates (469 B.C. - 399 B.C.), he mentioned scurvy as pain in legs, gangrene of gums and loss of teeth as a symptoms complex. Later in around
1497, the disease was observed in sea explorers and in the voyage of Vasco da Gama. The disease caused death of about $2 / 3 \mathrm{rd}$ of the crew members. In 1553 voyage team of Jacques Cartier suffered from the same symptoms, many members died and many got cured after taking tea prepared from the bark and leaves of spruce tree. Few more sailors and voyages explained the occurrence of scurvy in the later years but scientific explanations was given by a English navy surgeon, James Lind in "Treatise on Scurvy" in $1753 .{ }^{4}$

The term 'scurvy' for the disease resulting from prolonged vitamin C deficiency had origins in 'scorbutus' (Latin), 'scorbut' (French), and 'Skorbut' (German). Scurvy was a common problem in the world's navies and is estimated to have affected 2 million sailors. In 1747 , James Lind conducted a trial of six different treatments for 12 sailors with scurvy: only oranges and lemons were effective in treating scurvy. Scurvy also occurred on land, as many cases occurred with the 'great potato famine' in Ireland in 1845. ${ }^{93}$

The first reported manuscript available in Medline was in 1847 by Dr. T Shatter. He described three stages of this deficiency. In the first stage he stated that the appearance was characterized by the general and usual indications of debility, feelings of weakness and disinclination to exertion, nervousness, oppression of the breathing, with a feeling of faintness, attacks of chills, superficial pains of the limbs, facial, labial, glossal and gingival paleness, with small and soft pulse.

In the second stage, there is feeling of debility, nervousness is less intense, the respiration is slightly accelerated, hearing is mildly oppressed, and attacks of faintness occasionally supervene; the general body pain is increased, spongy and swollen gingiva which bleeds easily, halitosis, occurrence of petechial spots on the limbs, general bruising of the skin, the pulse is small, feeble, and slightly accelerated, occasional attacks of fever, in few cases joints are stiff, enlarged and painful, formation of nodes on the clavicle, sternum, and tibia.

In the third and last stage, he observed depressed breathing, a sinuous discharge on coughing, swollen and painful gingiva, fetid breath, discharge of body fluid, appearance of petechiae and tendency to bleeding from the gingiva and mucous surfaces of the vagina and rectum, formation of serous effusion on the neural membranes leading to confused state of mind..$^{94}$

\section{Sources}

Plant derivatives are superior sources of vitamin C. ${ }^{95}$ Since humans cannot synthesise $\mathrm{VC}$, their principle source of the vitamin is dietary fruit and vegetables. ${ }^{96}$ Hampl et al. ${ }^{97}$ conducted a survey on diet of school children and concluded that children consuming higher fruits and vegetables had higher level of VC and were more healthy. In 2004 Hung et al. ${ }^{98}$ stated that higher consumption of fruits and vegetables was associated with a comparable decrease in major chronic disease risk and further supported the recommendation of consuming five or more servings of fruits and vegetables daily. ${ }^{98}$ The content of VC in fruits and vegetables varies in a wide range and it even varies from the condition of the fruit and vegetable, raw plant product has the highest content of the vitamin, there is decrease in the content of VC with increase in storage temperature and duration. $\mathrm{VC}$ is sensitive to chemical and enzymatic oxidation during the processing and cooking. ${ }^{5}$ Other factors that affect the content of VC are oxygen, heat and light (Tables 1-5). ${ }^{99-101}$ 
Table I Highest sources of Vitamin C (Vegetables - Raw) (values are in $\mathrm{mg} / \mathrm{l00gm}$ )

\begin{tabular}{|c|c|c|}
\hline Sr. no. & Source & Vitamin $C$ content $(\mathrm{mg} / \mathrm{l} 00 \mathrm{gm})$ \\
\hline I & Pepper, hot chili, green & 242 \\
\hline 2 & Pepper, sweet, yellow & 183 \\
\hline 3 & Peppers, hot chili, red & 143 \\
\hline 4 & Drumstick pods & |4| \\
\hline 5 & Pokeberry shoots & 136 \\
\hline 6 & Parsley, fresh & 133 \\
\hline 7 & Mustard spinach, tender green & 130 \\
\hline 8 & Kale & 120 \\
\hline 9 & Peppers, jalepano & 118 \\
\hline 10 & Vine spinach (basella) & 102 \\
\hline II & Taro, tahitian, raw & 96 \\
\hline 12 & Broccoli leaves and flower cluster & 93 \\
\hline 13 & Pepper, Hungarian & 92 \\
\hline 14 & Cauliflower, green & 88 \\
\hline 15 & Bitter gourd, leafy tips & 88 \\
\hline 16 & Brussels sprouts & 85 \\
\hline 17 & Lambs quarter & 80 \\
\hline 18 & Sesbania flower & 73 \\
\hline 19 & Mustard green & 70 \\
\hline 20 & Cress, garden & 69 \\
\hline
\end{tabular}


Table 2 Highest sources of Vitamin C (Fruits - Raw) (values are inmg/l00gm)

\begin{tabular}{|c|c|c|}
\hline Sr. no. & Source & $\begin{array}{l}\text { Vitamin } C \text { content } \\
(\mathrm{mg} / \mathrm{l00g})\end{array}$ \\
\hline I & Camu camu (Justi et al., 2000) & 2800 \\
\hline 2 & Acerola & 1667 \\
\hline 3 & Guava & 228 \\
\hline 4 & Lemon & 182 \\
\hline 5 & Currants, European black & $|8|$ \\
\hline 6 & Kiwifruit & 92 \\
\hline 7 & Longans & 84 \\
\hline 8 & Litchi & 71 \\
\hline 9 & Orange with peel & 71 \\
\hline 10 & Jujube & 69 \\
\hline 11 & Persimmons, native & 66 \\
\hline 12 & Pummelo & 61 \\
\hline 13 & Papaya & 60 \\
\hline 14 & Strawberries & 58 \\
\hline 15 & Abiyuch & 54 \\
\hline 16 & Clementines & 48 \\
\hline 17 & Pineapple & 47 \\
\hline 18 & Kumquats & 43 \\
\hline 19 & Grapefruit, pink and red, California and Arizona & 38 \\
\hline 20 & Carissa (natal plum) & 38 \\
\hline
\end{tabular}


Table 3 Vegetable sources of Vitamin C and effect of food processing on Vitamin C content (values are in $\mathrm{mg} / 100 \mathrm{gm}$ )

\begin{tabular}{|c|c|c|c|c|c|}
\hline Sr. no. & Source (vegetable) & Raw & Canned & Cooked & Frozen \\
\hline I & Pepper, sweet, red & 127.7 & 46.5 & - & 58.7 \\
\hline 2 & Kale & 120 & - & 41 & 39.3 \\
\hline 3 & Broccoli & 89.2 & - & 64.9 & 56.4 \\
\hline 4 & Pepper, sweet, green & 80.4 & 46.5 & 74.4 & 58.7 \\
\hline 5 & Mustard green & 70 & - & 25.3 & 25.3 \\
\hline 6 & Peas, edible-podded & 60 & - & 47.9 & 22 \\
\hline 7 & Cabbage, red & 57 & - & 34.4 & - \\
\hline 8 & Cauliflower & 48.2 & - & 44.3 & 48.8 \\
\hline 9 & Peas, green & 40 & 7.8 & 14.2 & 18 \\
\hline 10 & Kidney beans & 38.7 & - & 35.6 & - \\
\hline II & Spinach & 28.1 & 13.5 & 9.8 & 5.5 \\
\hline 12 & Lima beans & 23.4 & - & 16.3 & 12.4 \\
\hline 13 & Okra (lady finger) & 23 & - & 16.3 & 12.4 \\
\hline 14 & Radish oriental & 22 & - & 15.1 & - \\
\hline 15 & Beans pinto & 21.7 & 0.7 & 6.1 & - \\
\hline 16 & Turnips & 21 & - & 11.6 & 4.4 \\
\hline
\end{tabular}

Table 4 Fruit sources of Vitamin $C$ and effect of food processing on Vitamin $C$ content (values are in $\mathrm{mg} / 100 \mathrm{gm}$ )

\begin{tabular}{llllll}
\hline Sr. No. & Source & Raw & Dried & Frozen & Canned \\
\hline 1 & Lemon & 182 & - & 31.5 & - \\
2 & Longans & 84 & 28 & - & - \\
3 & Jujube & 69 & 13 & - & - \\
4 & Papaya & 60.9 & - & - & 3.5 \\
5 & Strawberries & 58.8 & - & 41.2 & - \\
6 & Pineapple & 47.8 & - & 8 & 7.4 \\
7 & Mangoes & 36.4 & - & - & 15.2 \\
8 & Gooseberry & 27.7 & - & - & 10 \\
9 & Raspberries & 26.2 & - & 16.5 & 8.7 \\
10 & Blackberry & 21 & - & 3.1 & 2.8
\end{tabular}


Table 5 Fruit Juice and content of Vitamin C (values are in $\mathrm{mg} / \mathrm{l00gm}$ )

\begin{tabular}{lllll}
\hline Sr. no. & Source & Raw & Frozen & Canned \\
\hline 1 & Orange juice & 50 & 137.9 & 30.1 \\
2 & Grapefruit juice & 38 & 119.8 & 29.2 \\
3 & Tangerine juice & 31 & 85.1 & 22 \\
4 & Lime juice & 30 & - & 6.4 \\
5 & Passion fruit, purple, juice & 29.8 & - & - \\
6 & Cranberry juice & 9.8 & - & - \\
7 & Pomegranate juice & 0.1 & - & - \\
8 & Pineapple juice & - & 42 & 10 \\
9 & Blackberry juice & - & - & 11.3 \\
10 & Apple juice & - & 2.1 & 0.9 \\
\hline
\end{tabular}

\section{Excess dosage}

The toxicity of $\mathrm{VC}$ is low but doses crossing upper intake level may cause diarrhoea, abdominal cramps, gastrointestinal disturbances, flatus and nausea. Other than these there is increase in formation renal stones and the mechanism behind it is conversion of $\mathrm{VC}$ to oxalate and the property of acidifying urinary. ${ }^{102,103}$ In a study it was observed that on intake of $1000 \mathrm{mg}$ of supplemental VC given twice daily increased the level of excretion of oxalate by upto $22 \% .{ }^{104}$ Another study in men administered $1000 \mathrm{mg}$ or more of $\mathrm{VC}$ had about $49 \%$ higher risk of stone formation than in men consuming dose lesser than $90 \mathrm{mg} /$ day. ${ }^{105}$ In patients suffering from hereditary hemochromatosis it has been seen that excessive VC intake results in increased iron overload and tissue damage, no such results have been presented in normal individuals. Other effects of VC toxicity include reduced vitamin B12 and copper levels, erosion of dental enamel, and allergic responses (Table 6). ${ }^{102,103}$

Table 6 Recommended daily allowance

\begin{tabular}{|c|c|c|}
\hline Sr. no. & Individual & Recommended daily allowance (RDA) \\
\hline & Pediatric & \\
\hline I & Birth - 6months (M \& F) & $40 \mathrm{mg}$ \\
\hline 2 & Infants 6-I 2months (M \& F) & $50 \mathrm{mg}$ \\
\hline 3 & Children I-3years (M \& F) & $15 \mathrm{mg}$ \\
\hline 4 & Children 4-8years (M \& F) & $25 \mathrm{mg}$ \\
\hline 5 & Children 9-I3years (M \& F) & $45 \mathrm{mg}$ \\
\hline 6 & Adolescent female I4-I8years & $65 \mathrm{mg}$ \\
\hline 7 & Adolescent male 14-18years & $75 \mathrm{mg}$ \\
\hline 8 & Pregnant female 14-18years & $80 \mathrm{mg}$ \\
\hline \multirow[t]{2}{*}{9} & Lactating female 14-18years & $115 \mathrm{mg}$ \\
\hline & Adults & \\
\hline 10 & Male over I8years & $90 \mathrm{mg}$ \\
\hline II & Female over I8years & $75 \mathrm{mg}$ \\
\hline 12 & Pregnant female over I8years & $85 \mathrm{mg}$ \\
\hline 13 & Lactating female over I8years & $120 \mathrm{mg}$ \\
\hline
\end{tabular}




\section{Conclusion}

From the data mentioned it can be observed that Vitamin $\mathrm{C}$ has a long list of treating as well as preventing systemic diseases. If taken on a regular basis can be highly sanative for the human body. As mentioned, human beings are unable to synthesize Vitamin $\mathrm{C}$ and require an external source to fulfil the recommended daily allowance and fruits and vegetables are its richest sources. We jotted down the sources of Vitamin $\mathrm{C}$ along with impact of food processing on the concentration of the vitamin in the plant source and recommend increased consumption of these plant sources.

\section{Acknowledgements}

The author reports no conflict of interests. It is a self-funded research. The author would like to thank Mrs. Parul Jain.

\section{Conflict of interest}

Author declares that there is no conflict of interest.

\section{References}

1. Drummond JC. The Nomenclature of the so-called Accessory Food Factors (Vitamins). Biochem J. 1920;14(5):660.

2. Funk C, Dubin HE. The Vitamines. Baltimore: Williams and Wilkins Company. Baltimore, USA. 1922.

3. Kastner U. Vitamin C. Munich: GRIN Publishing; 2001.

4. Talwar GP, Srivastava LM. Textbook of Biochemistry and Human Biology. 3rd edn India: PHI Learning Pvt. Ltd; 2003.

5. Lee SK, Kader AA. Preharvest and postharvest factors influencing vitamin C content of horticultural crops. Postharvest Biol Technol. 2000;20:207-220.

6. Smirnoff N, Conklin PL, Loewus FA. Biosynthesis of ascorbic acid in plants: a renaissance. Annu Rev Plant Physiol Plant Mol Biol. 2001;52:437-467.

7. Ohta Y, Nishikimi M. Random nucleotide substitutions in primate nonfunctional gene for l-gulono-gamma-lactone oxidase, the missing enzyme in 1-ascorbic acid biosynthesis. Biochim Biophys Acta. 1999;1472(1-2):408-411.

8. MacDonald L, Thumser AE, Sharp P. Decreased expression of the vitamin $\mathrm{C}$ transporter SVCT1 by ascorbic acid in a human intestinal epithelial cell line. Br J Nutr. 2002;87(2):97-100.

9. Hornig D. Metabolism and requirements of ascorbic acid in man. $S A f r$ Med J. 1981;60(21):818-823.

10. McLaughlin JK, Gridley G, Block G, et al. Dietary factors in oral and pharyngeal cancer. JNCI. 1988;80(15):1237-1243.

11. Graham S, Mettlin C, Marshall I, et al. Dietary factors in the epidemiology of cancer of the larynx. Am I Epidemiol. 1981;113(6):675-680.

12. Brown LM, Blot WI, Schuman SH, et al. Environmental factors and high risk of esophageal cancer among men in coastal South Carolina. J Natl Cancer Inst. 1988;80(20):1620-1625.

13. Tuyns A. Protective effect of citrus fruit on esophageal cancer. Nutr Cancer. 1983;5(3-4):195-200.

14. Ziegler RG, Moms LE, Blot WI, et al. Esophageal cancer among black men in Washington, DC. II. Role of nutrition. J Natl Cancer Inst. 1981;67(6):1199-1206.

15. Fontham ETH, Pickle LW, Haenszel W, et al. Dietary vitamins A and $\mathrm{C}$ and lung cancer risk in Louisiana. Cancer. 1988;62(10):2267-2273.
16. Kromhout D. Essential micronutrients in relation to carcinogenesis. Am J Clin Nutr. 1987;45(5 Suppl):1361-1367.

17. Falk RT, Pickle LW, Fontham ET, et al. Life- style risk factors for pancreatic cancer in Louisiana: a case-control study. Am J Epidemiol. 1988;128(2):324-336.

18. Mills PK, Beeson WL, Abbey DE, et al. Dietary habits and past medical history as related to fatal pancreas cancer risk among Adventists. Cancer. 1988;61(12):2578-2785.

19. Bjelke E. Case-control study of cancer of the stomach, colon, and rectum. In: Clark RL, editor. Oncology: Being the Proceedings of the Tenth International Cancer Congress. Chicago: Yearbook Medical Publishers; 1970. p. 320-334.

20. Verreault R, Chu I, Mandelson M, et al. A case-control study of diet and invasive cervical cancer. Int J Cancer. 1989;43(6):1050-1054.

21. Kune S, Kune GA, Watson LF. Case-control study of dietary etiological factors: the Melbourne colorectal cancer study. Nutr Cancer. 1987;9(1):21-42.

22. Kyrtopoulos SA. Ascorbic acid and the formation of N-nitroso compounds: possible role of ascorbic acid in cancer prevention. Am J Clin Nutr. 1987;45(5):1344-1350.

23. Mikirova N, Casciari J, Rogers A, et al. Effect of high-dose intravenous vitamin $\mathrm{C}$ on inflammation in cancer patients. J Transl Med. 2012;10:189.

24. Wen Y, Cooke T, Feely J. The effect of pharmacological supplementation with vitamin $\mathrm{C}$ on low-density lipoprotein oxidation. $\mathrm{Br} \mathrm{J}$ Clin Pharmacol. 1997;44(1):94-97.

25. Retsky KL, Freeman MW, Frei B. Ascorbic acid oxidation product (s) protect human low density lipoprotein against atherogenic modification. Anti- rather than prooxidant activity of vitamin $\mathrm{C}$ in the presence of transition metal ions. J Biol Chem. 1993;268(2):1304-1309.

26. Retsky KL, Frei B. Vitamin C prevents metal ion-dependent initiation and propagation of lipid peroxidation in human low-density lipoprotein. Biochim Biophys Acta. 1995;1257(3):279-287.

27. Liu ZQ, Ma LP, Liu ZL. Making vitamin C lipophilic enhances its protective effect against free radical induced peroxidation of low density lipoprotein. Chem Phys Lipids. 1998;95(1):49-57.

28. Hallfrisch J, Singh VN, Muller DC, et al. High plasma vitamin C associated with high plasma HDL- and HDL2 cholesterol. Am J Clin Nutr. 1994;60(1):100-105.

29. Trout DL. Vitamin C and cardiovascular risk factors. Am J Clin Nutr. 1991;53(1):322S-325S.

30. Vita JA, Keaney JF Jr. Endothelial function: a barometer for cardiovascular risk? Circulation. 2002;106(6):640-642.

31. Gokce N, Keaney JF Jr, Frei B, et al. Long-term ascorbic acid administration reverses endothelial vasomotor dysfunction in patients with coronary artery disease. Circulation. 1999;99(25):3234-3240.

32. Versari D, Daghini E, Virdis A, et al. Endothelium-dependent contractions and endothelial dysfunction in human hypertension. $\mathrm{Br} J$ Pharmacol. 2009;157(4):527-536.

33. Frikke-Schmidt H, Lykkesfeldt J. Role of marginal vitamin C deficiency in atherogenesis: in vivo models and clinical studies. Basic Clin Pharmacol Toxicol. 2009;104(6):419-433.

34. Ness AR, Chee D, Elliott P. Vitamin C and blood pressure-an overview. J Hum Hypertens. 1997;11(6):343-350.

35. Wang C, Liang J, Zhang C, et al. Effect of ascorbic acid and thiamine supplementation at different concentrations on lead toxicityin liver. Ann Occup Hyg. 2007;51(6):563-569. 
36. Ebuehi OA, Ogedegbe RA, Ebuehi OM. Oral administration of vitamin $\mathrm{C}$ and vitamin $\mathrm{E}$ ameliorates lead-induced hepatotoxicity and oxidative stress in the rat brain. Nig Q J Hosp Med. 2012;22(2):85-90.

37. Suzuki T, Yoshida A. Effects of dietary supplementation of iron and ascorbic acid on lead toxicity in rats. J Nutr. 1979;109(6):983-988.

38. Goyer RA, Cherian MG. Ascorbic acid and EDTA treatment of lead toxicity in rats. Life Sci. 1979;24(5):433-438.

39. Vij AG, Satija NK, Flora SJ. Lead induced disorders in hematopoietic and drug metabolizing enzyme system and their protection by ascorbic acid supplementation. Biomed Environ Sci. 1998;11(1):7-14.

40. Han JM, Chang BJ, Li TZ, et al. Protective effects of ascorbic acid against lead-induced apoptotic Neuroregeneration in the developing rat hippocampus in vivo. Brain Res. 2007;1185:68-74.

41. Gabbay KH, Bohren KM, Morello R, et al. Ascorbate synthesis pathway: dual role of ascorbate in bone homeostasis. $J$ Biol Chem. 2010;285(25):19510-19520.

42. Urban K, Hohling HJ, Luttenberg B, et al. An in vitro study of osteoblast vitality influenced by the vitamins C and E. Head Face Med. 2012;8:25.

43. Sahni S, Hannan MT, Gagnon D, et al. High vitamin C intake is associated with lower 4-year bone loss in elderly men. J Nutr. 2008;138(10):1931-1938.

44. Rodriguez S, Paniagua O, Nugent KM, et al. Regional transien osteoporosis of the foot and vitamin $\mathrm{C}$ deficiency. Clin Rheumatol. 2007;26(6):976-978.

45. Lynch SR, Berelowitz I, Seftel HC, et al Osteoporosis in Johannesburg Bantu males. Its relationship to siderosis and ascorbic acid deficiency. Am J Clin Nutr. 1967;20(8):799-807.

46. Reiss GR, Werness PG, Zollman PE, et al. Ascorbic acid levels in the aqueous humor of nocturnal and diurnal mammals. Arch Ophthalmol. 1986;104(5):753-755.

47. Dherani M, Murthy GV, Gupta SK, et al. Blood levels of vitamin $\mathrm{C}$, carotenoids and retinol are inversely associated with cataract in a North Indian population. Invest Ophthalmol Vis Sci. 2008;49(8):3328-3335.

48. Ringvold A. Aqueous humor and ultraviolet radiation. Acta Ophthalmol (Copenh). 1980;58(1):69-82.

49. Varma SD, Kumar S, Richards RD. Light induced damage to ocular lens cation pump: prevention by vitamin C. Proc Nat Acad Sci USA. 1979;76(4):3504-3506.

50. Varma SD, Richards RD. Ascorbic acid and the eye lens. Ophthalmic Res. 1988;20(3):164-173.

51. Varma SD, Srivastava VK, Richards RD. Photoperoxidation in lens and cataract formation: preventive role of superoxide dismutase, catalase and vitamin C. Ophthalmic Res. 1982;14(3):167-175.

52. Jacques PF, Chylack LT Jr, Hankinson SE, et al. Long-term nutrient intake and early age-related nuclear lens opacities. Arch Ophthalmol. 2001;119(7):1009-1019.

53. Yoshida M, Takashima $\mathrm{Y}$, Inoue $\mathrm{M}$, et al. Prospective study showing that dietary vitamin $\mathrm{C}$ reduced the risk of age-related cataracts in a middleaged Japanese population. Eur J Nutr. 2007;46(2):118-124.

54. Simon JA, Hudes ES. Serum ascorbic acid and other correlates of self-reported cataract among older Americans. J Clin Epidemiol. 1999;52(12):1207-1211.

55. Ravindran RD, Vashist $\mathrm{P}$, Gupta $\mathrm{SK}$, et al. Inverse association of vitamin $\mathrm{C}$ with cataract in older people in India. Ophthalmology. 2011;118(10):1958-1965.
56. McCarty CA, Taylor HR. Recent developments in vision research: light damage in cataract. Invest Ophthalmol Vis Sci. 1996;37(9):1720-1723.

57. Gao X, Curhan G, Forman JP, et al. Vitamin C intake and serum uric acid concentration in men. J Rheumatol. 2008;35(9):1853-1858.

58. Enomoto A, Kimura H, Chairoungdua A, et al. Molecular identification of a renal urate anion exchanger that regulates blood urate levels. Nature. 2002;417(6887):447-452.

59. Huang HY, Appel LJ, Choi MJ, et al. The effects of vitamin C supplementation on serum concentrations of uric acid: results of a randomized controlled trial. Arthritis Rheum. 2005;52(6):1843-1847.

60. Juraschek SP, Miller ER, Gelber AC. Effect of oral vitamin C supplementation on serum uric acid: a meta-analysis of randomized controlled trials. Arthritis Care Res (Hoboken). 2011;63(9):1295-1306.

61. Rodahl K. The Toxic Effect of Polar Bear Liver. I kommisjon hos $J$ Dybwad. 1949.

62. Wendt H, Schroeder H. Antagonismus Der Vitamine A Und C. Intern Z Viaininfrlisch. 1935;4:206-212.

63. Cunningham JJ. The glucose insulin system and vitamin $\mathrm{C}$ : implications in insulindependent diabetes mellitus. J Am Coll Nutr. 1998;17(2):105-108.

64. Osganian SK, Stampfer MJ, Rimm E, et al. Vitamin C and risk of coronary heart disease in women. $J$ Am Coll Cardiol. 2003;42(2):246-252.

65. Levy AP, Friedenberg P, Lotan R, et al. The effect of vitamin therapy on the progression of coronary artery atherosclerosis varies by haptoglobin type in postmenopausal women. Diabetes Care. 2004;27(4):925-930.

66. Sridulyakul P, Wongeak-In N, Patumraj S. Correlations between endothelial functions and ROS detection in Diabetic Microvascular Wall: Early and Late Ascorbic Acid Supplementation. Int J Vasc Med. 2012;2012:709695.

67. Dakhale GN, Chaudhari HV, Shrivastava M. Supplementation of vitamin $\mathrm{C}$ reduces blood glucose and improves glycosylated hemoglobin in type 2 diabetes mellitus: a randomized, double-blind study. $A d v$ Pharmacol Sci. 2011;2011:195271

68. Owu DU, Obembe AO, Nwokocha CR, et al. Gastric ulceration in diabetes mellitus: protective role of vitamin C. ISRN Gastroenterol. $2012 ; 2012: 362805$.

69. Smith CD, Carney JM, Starke-Reed PE, et al. Excess brain protein oxidation and enzyme dysfunction in normal aging and in Alzheimer disease. Proc Natl Acad Sci U S A. 1991;88(23):10540-10543.

70. Charlton KE, Rabinowitz TL, Geffen LN, et al. Lowered plasma vitamin $\mathrm{C}$, but not vitamin E, concentrations in dementia patients. J Nutr Health Aging. 2004;8(2):99-107.

71. Perrig WJ, Perrig P, Stahelin HB. The relation between antioxidants and memory performance in the old and very old. $J$ Am Geriatr Soc. 1997;45(6):718-724.

72. Goodwin JS, Goodwin JM, Garry PJ. Association between nutritional status and cognitive functioning in a healthy elderly population. JAMA. 1983;249(21):2917-2921.

73. Woo J, Ho SC, Mak YT, et al. Association between mental and nutritional status in a healthy elderly Chinese population. Res Commun Psychol Psychiatr Behav. 1989;14:85-97.

74. Schwartz J, Weiss ST. Relationship between dietary vitamin C intake and pulmonary function in the First National Health and Nutrition Examination Survey NHANES I. Am J Clin Nutr. 1994;59(1):110-114.

75. Soutar A, Seaton A, Brown K Bronchial reactivity and dietary antioxidants. Thorax. 1997;52(2):166-170. 
76. Schachter EN, Schlesinger A. The attenuation of exercise-induced bronchospasm by ascorbic acid. Ann Allergy. 1982;49(3):146-151.

77. Patel BD, Welch AA, Bingham SA, et al Dietary antioxidants and asthma in adults. Thorax. 2006;61(5):388-393.

78. Anah CO, Jarike LN, Baig HA. High dose ascorbic acid in Nigerian asthmatics. Trop Geogr Med. 1980;32(2):132-137.

79. Anderson R, Hay I, van Wyk HA, et al. Ascorbic acid in bronchial asthma. S Afr Med J. 1983;63(17):649-652.

80. Rubin RN, Navon L, Cassano PA. Relationship of serum antioxidants to asthma prevalence in youth. Am J Respir Crit Care Med. 2004;169(3):393-398.

81. Baker JC, Tunnicliffe WS, Duncanson RC, et al. Dietary antioxidants and magnesium in type 1 brittle asthma: a case control study. Thorax. 1999;54(2):115-118.

82. Cameron E, Pauling L. Supplemental ascorbate in the supportive treatment of cancer: Prolongation of survival times in terminal human cancer. Proc Natl Acad Sci U S A. 1976;73(10):3685-3689.

83. Gottlieb N. Cancer treatment and vitamin C: debate lingers. $J$ Natl Cancer Inst. 1999;91(24):2073-2075.

84. Ohno S, Ohno Y, Suzuki N, et al. High-dose vitamin C (ascorbic acid) therapy in the treatment of patients with advanced cancer. Anticancer Res. 2009;29(3):809-815.

85. An SH, Kang JH, Kim DH, et al. Vitamin C increases the apoptosis via up-regulation p53 during cisplatin treatment in human colon cancer cells. BMB Rep. 2011;44(3):211-216.

86. Prasad KN, Hernandez C, Edwards-Prasad J, et al. Modification of the effect of tamoxifen, cisplatin, DTIC, and interferon-alpha $2 \mathrm{~b}$ on human melanoma cells in culture by a mixture of vitamins. Nutr Cancer. 1994;22(3):233-245.

87. Kurbacher CM, Wagner U, Kolster B, et al. Ascorbic acid (vitamin C) improves the antineoplastic activity of doxorubicin, cisplatin, and paclitaxel in human breast carcinoma cells in vitro. Cancer Lett. 1996;103(2):183-189.

88. Taper HS, de Gerlache J, LANs M, et al. Non-toxic potentiation of cancer chemotherapy by combined $\mathrm{C}$ and $\mathrm{K} 3$ vitamin pre-treatment. Int J Cancer. 1987;40(4):575-579.

89. Diehl HS, Baker AB, Cowan DW. Cold vaccines: an evaluation based on a controlled study. J Am Med Assoc. 1938;111(13):1168-1173.

90. Nahas R, Balla A. Complementary and alternative medicine for prevention and treatment of the common cold. Can Fam Physician. 2011;57(1):31-36.
91. Constantini NW, Dubnov-Raz G, Eyal BB, et al. The effect of vitamin $\mathrm{C}$ on upper respiratory infections in adolescent swimmers: a randomized trial. Eur J Pediatr. 2011;170(1):59-63.

92. Maggini S, Beveridge S, Suter M. A combination of high-dose vitamin C plus zinc for the common cold. J Int Med Res. 2012;40(1):28-42.

93. Carpenter KJ. The discovery of vitamin C. Ann Nutr Metab. 2012;61(3):259-264.

94. Shapter T. On the Recent Occurrence of Scurvy in Exeter and the Neighbourhood. Prov Med Surg J. 1847;11(11):281-285.

95. Levine M, Rumsey SC, Daruwala R, et al. Criteria and recommendations for vitamin intake. JAMA. 1999;281(15):1415-1423.

96. Jawaheer S, White SF, Rughooputh SD, et al. Development of a common biosensor format for an enzyme based biosensor array to monitor fruit quality. Biosens Bioelectron. 2003;18(12):1429-1437.

97. Hampl JS, Taylor CA, Johnston CS Intakes of vitamin $\mathrm{C}$, vegetables and fruits: which school children are at risk? J Am Coll Nutr. 1999;18(6):582-589.

98. Hung HC, Joshipura KJ, Jiang R, et al. Fruit and vegetable intake and risk of major chronic disease. J Natl Cancer Inst. 2004;96(21):1577-1584.

99. Burdurlu HS, Koca N, Karadeniz F. Degradation of vitamin C in citrus juice concentrates during storage. J Food Eng. 2006;74:211-216.

100. Nutrient Data Laboratory. USDA National Nutrient Database for Standard Reference. Release 23. United Stated Department of Agricultural Research Service. 2010.

101. Institute of Medicine Food and Nutrition Board. Dietary reference intakes for vitamin $C$, vitamin $E$, selenium and carotenoids. Washington, DC: National Academy Press; 2000.

102. Justi KC, Visentainer JV, Evelazio de Souza N, et al. Nutritional composition and vitamin $\mathrm{C}$ stability in stored camu-camu (Myrciaria dubia) pulp. Arch Latinoam Nutr. 2000;50(4):405-408.

103. Jacob RA, Sotoudeh G. Vitamin C function and status in chronic disease Nutr Clin Care. 2002;5(2):66-74

104. Taylor EN, Stampfer MJ, Curhan GC. Dietary factors and the risk of incident kidney stones in men: new insights after 14 years of followup. J Am Soc Nephrol. 2004;15(12):3225-3232.

105. Traxer O, Huet B, Poindexter J, et al. Effect of ascorbic acid consumption on urinary stone risk factors. J Urol. 2003;170(2 pt 1):397-401. 